\title{
OVER THE CLIFF
}

As pharmaceutical companies experience a slew of patent expiries, revenues will become much more exposed to competition from generic drugs.

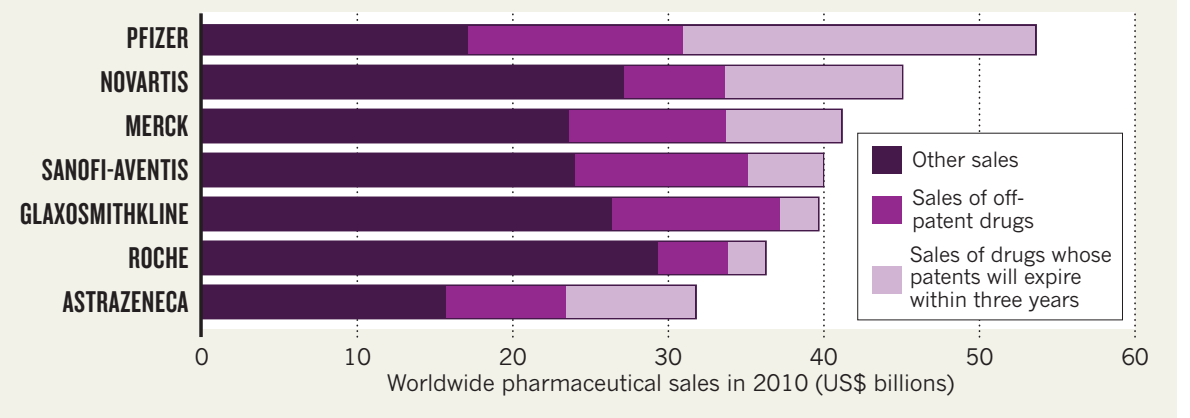

\section{Drug-maker plans to cut jobs and spending as industry shies away from drug discovery.}

\section{BY DANIEL CRESSEY}

$\mathrm{T}$ The pharmaceutical industry has spent years bracing itself for the 'patent cliff', when sales are expected to plummet as a bundle of blockbuster drugs loses protection against generic competitors.

Yet the dire consequences for drug research - and the scientists behind it - still took many by surprise last week. With key patents about to expire, Pfizer, the world's largest pharmaceutical company in terms of sales, unveiled plans to slash its research and development (R\&D) spending by billions and cut thousands of jobs.

The chief casualty is the company's research facility in Sandwich, UK, where the erectile dysfunction drug Viagra was developed. The site will close in 18-24 months, with almost all of the 2,400 employees there - mostly scientists - facing redundancy. Meanwhile, the company's R\&D headquarters in Groton, Connecticut, will be shedding roughly 1,100 jobs. Pfizer will also cut R\&D expenditure for 2012 to between US $\$ 6.5$ billion and $\$ 7.0$ billion, down from its previous target of $\$ 8$ billion to $\$ 8.5$ billion.

"There are going to be a lot of unemployed scientists," says Ashley Woodcock, head of the School of Translational Medicine at the University of Manchester, UK. He fears that Pfizer's cuts, on top of job culls announced by GlaxoSmithKline and AstraZeneca last year, will erode traditionally strong links between the drug industry and academia in Britain. "Having industry alongside academic research is what has made us great," says Woodcock, "and if the industry leaks away we'll be in real trouble."

Pfizer plans to ditch research into areas including allergy and respiratory diseases, which are based at its Sandwich site, although it is unlikely to completely abandon promising candidate drugs. The company plans to focus on neuroscience, oncology, vaccines, and cardiovascular and inflammation treatments.

This may not be the company's last retrench. London-based analysts EvaluatePharma expect patent expiries over the next three years to expose about two-thirds of Pfizer's total sales to competition from generics (see graph). This is largely a consequence of the company's reliance on its cholesterol-reducing drug Lipitor - the world's best-selling drug last year - which will lose patent protection in November.

Rival companies also face sales losses running into the billions. The latest parade of annual results shows that although profits are buoyant for now, companies are increasingly reluctant to sink money into R\&D pipelines, which have been slow to yield new drugs. Instead, share buy-backs - which boost share prices and please investors - and outsourcing $\mathrm{R} \& \mathrm{D}$ are in vogue.

GlaxoSmithKline last week said it would be spending between $£ 1$ billion (US $\$ 1.6$ billion) and $£ 2$ billion in 2011 as part of a "long-term share buy-back programme", and added that it has made "fundamental changes to how we allocate our R\&D expenditure". The company plans to focus its work on getting the most promising drugs to market and will cut costs and risk "through externalising parts of earlystage discovery; dismantling infrastructure; and terminating development in areas with low financial and scientific return".

"The pharma industry is deciding its core capabilities are marketing and dealing with regulatory bodies," says Judy Slinn, a business historian at Oxford Brooks University, UK. "Pharma companies will still do development work. They won't do discovery." - SEECOLUMN PI4I 